\title{
Effects of Different Harvest Times on Nutritional Component of Herbaceous Peony Flower Petals
}

\author{
Weixing Li $\mathbb{D},{ }^{1,2}$ Xiaomei Song, ${ }^{3,4}$ Yanmin Hua, ${ }^{1}$ Jun Tao $\mathbb{D}^{1,2}$ and Chunhua Zhou $\mathbb{D}^{1,2}$ \\ ${ }^{1}$ College of Horticulture and Plant Protection, Yangzhou University, Yangzhou 225009, China \\ ${ }^{2}$ Joint International Research Laboratory of Agriculture \& Agri-Product Safety of Ministry of Education of China, \\ Yangzhou University, Yangzhou 225009, China \\ ${ }^{3}$ College of Animal Science and Technology, Yangzhou University, Yangzhou 225009, China \\ ${ }^{4}$ Yangzhou Polytechnic Institute, Yangzhou 225127, China
}

Correspondence should be addressed to Chunhua Zhou; chzhou@yzu.edu.cn

Received 6 July 2020; Revised 16 September 2020; Accepted 8 October 2020; Published 22 October 2020

Academic Editor: Serkos A. Haroutounian

Copyright (c) 2020 Weixing Li et al. This is an open access article distributed under the Creative Commons Attribution License, which permits unrestricted use, distribution, and reproduction in any medium, provided the original work is properly cited.

Herbaceous peony (Paeonia lactiflora Pall.) flowers can be used as edible flowers, but few studies concerned about their edible values and the optimal harvest season. In this study, petals of three herbaceous peony cultivars including "Dafugui," "Hongyan Zhenghui," and "Yangfei Chuyu" at four different development stages were used as materials to measure the content of soluble sugar, organic acid, protein, vitamin C ( Vc), total phenolics, total flavonoids, mineral elements, and superoxide dismutase (SOD) activity, with the aim to understand the variation tendency of the nutritional ingredients and bioactive components in herbaceous peony flower petals during development and to determine the optimal harvest time for herbaceous peony flowers with better edible qualities. The results demonstrated that the content of individual nutritional and bioactive components was varied with cultivars and developmental stages. The soluble sugar content was 63.69-225.97 mg/g FW, organic acid 10.13-24.60 mg/g FW, soluble protein $9.83-39.17 \mathrm{mg} / \mathrm{g} \mathrm{FW}, \mathrm{Vc} 12.31-33.52 \mathrm{mg} / 100 \mathrm{~g} \mathrm{FW}$, total phenolics $83.23-136.19 \mathrm{mg} / \mathrm{g}$ DW, total flavonoids 10.20-24.98 mg/g DW, and SOD activity 62.92-284.09 U/g FW. For mineral elements, the content of Na, Mg, K, Ca, Mn, Fe, Ni, and Zn was 20.96-65.51 $\mu \mathrm{g} / \mathrm{g}$ DW, 810.85-1342.36 $\mu \mathrm{g} / \mathrm{g}$ DW, 6723.68-12253.63 $\mu \mathrm{g} / \mathrm{g}$ DW, 848.67-3038.46 $\mu \mathrm{g} / \mathrm{g} \mathrm{DW}, 1.14-8.44 \mu \mathrm{g} /$ g DW, 48.70-149.72 $\mu \mathrm{g} / \mathrm{g} \mathrm{DW}, 1.20-2.17 \mu \mathrm{g} / \mathrm{g}$ DW, and 16.69-25.50 $\mu \mathrm{g} / \mathrm{g} \mathrm{DW}$, respectively. The content of soluble sugar, protein, total flavonoids, and SOD activity in flower petals was the highest, and the content of organic acid was the lowest at the full bloom period (S3) for all three cultivars, while the highest Vc and total phenolics were at the early bloom stage (S2) and flower bud stage (S1), respectively. In conclusion, it is recommended to harvest herbaceous peony flowers at S3 with the best edible quality considering nutrients and bioactive components.

\section{Introduction}

Edible flowers have been used in culinary preparations for centuries to improve the nutritional, sensorial, and aesthetic qualities of food [1-3] and are popular topics of different magazine articles, making an excellent illustration opportunity [4]. Moreover, they also have been used in Chinese traditional medicine since ancient times, but its nutritional value has not been studied in depth [5]. Previous studies demonstrated that edible flowers contain numerous phytochemicals, including sugar, acid, protein, amino acid, minerals, flavonoids, polyphenols, anthocyanins, carotenoids, and fiber [2, 6-14], which contribute to their biological activity and high antioxidant capacity [12-19], and are eventually beneficial to consumers' health [1]. In recent years, consumption of edible flowers has increased significantly $[4,20]$. Previous investigations revealed that collection stage of the flowers had a significant effect on the content of chemical compositions [21-23]. Herbaceous peony (Paeonia lactiflora Pall.) is a wonderful ornamental plant and has various cultivars with different flower colors and types [24]. The roots, leaves, and flowers of herbaceous peony contain different components and have edible and medicinal values [24-30]. Until now, research studies of 
herbaceous peony were mainly involved in flower ornamental value [24] and root medicinal value [31], especially the underlying mechanisms of flower pigmentation [32-34]. The herbaceous peony flowers harvested at unfold-peta stage had longer vase life and opening life with no significantly reduced ornamental quality [35]. However, few studies concerned about the edible value of herbaceous peony petals and the optimal harvest season. In this study, petals of three cultivars were selected to perform nutritional quality analysis to understand the variation tendency of the nutritional ingredients and bioactive components in herbaceous peony flower petals at different developmental stages and finally to determine the optimal flower petal harvest time for herbaceous peony flowers with better edible qualities.

\section{Materials and Methods}

2.1. Plant Materials. Three P. lactiflora cultivars including "Dafugui" (rose red), "Hongyan Zhenghui" (purple), and "Yangfei Chuyu" (white) were used as materials at first (Figure 1). Flowers of three cultivars were sampled at four different developmental stages, i.e., flower bud stage (S1), early bloom stage (S2), full bloom (S3) stage, and flower decline stage (S4) from March to May, 2014. All the plant materials were collected from Peony Germplasm Resource Garden of Yangzhou University (Yangzhou, China). The petals were detached from flowers, some petals were dried to a constant weight in an oven at $60^{\circ} \mathrm{C}$ and used to determine the contents of mineral elements, total phenolics, and total flavonoids, and the rest petals were immediately frozen with liquid nitrogen and stored in $-80^{\circ} \mathrm{C}$ ultralow temperature refrigerator used to measure the contents of soluble sugar, organic acid, protein, Vc, and SOD activity.

\subsection{Methods}

2.2.1. Determination of Nutritional and Bioactive Components. Soluble sugar content was measured with an anthrone colorimetry at $630 \mathrm{~nm}$ wavelength [36]. Organic acid content was determined by acid-base titration with $0.02 \mathrm{~mol} / \mathrm{L} \mathrm{NaOH} \mathrm{[36].} \mathrm{Protein} \mathrm{content} \mathrm{was} \mathrm{obtained} \mathrm{by}$ Coomassie brilliant blue G-250 staining under $595 \mathrm{~nm}$ wavelength [36]. Vc content was analyzed using 2,6dichloro-indigo colorimetry until the solution color changed from blue to pink [37]. Mineral element content was determined with a Thermo Fisher ICAP 6300 ICP instrument (Thermo Fisher, USA) according the method of Du et al. [38]. Total flavonoid content was determined using the $\mathrm{Al}\left(\mathrm{NO}_{3}\right)_{3}-\mathrm{NaNO}_{2}$ colorimetry method with rutin as standard [16]. Total phenolic content was determined using Folin-Ciocalteu reagent with gallic acid as standard [39]. SOD activity was measured with reagent kits from Nanjing Jiancheng Biological Co. Ltd. (Nanjing, China) according to the operation instruction. SOD inhibition rate was calculated in $1 \mathrm{~mL}$ reaction mixture per gram fresh weight of petals. All above analyses were repeated three times.

2.2.2. Statistical Analysis. Single factor variance analysis was performed on nutritional quality data of three main cultivated varieties with IBM SPSS 20 software, and multiple comparison was conducted on average value of three repeats using Duncan's new multiple range difference method, and thus, the best harvest period of herbaceous peony flower was established.

\section{Results}

\subsection{Nutritional Component}

3.1.1. Soluble Sugar. The soluble sugar content variation in petals of three cultivars during development showed similar tendency, with initial increase and then decrease. The highest level appeared in the period of S3, with the value of $202.93 \pm 1.53 \mathrm{mg} / \mathrm{g} \mathrm{FW}, 133.21 \pm 2.07 \mathrm{mg} / \mathrm{g} \mathrm{FW}$, and $225.97 \pm 0.99 \mathrm{mg} / \mathrm{g} \mathrm{FW}$ for "Dafugui," "Hongyan Zhenghui," and "Yangfei Chuyu," respectively, which is more than 1.8 times compared with the lowest content of S1 period. Between three cultivars, the order of soluble sugar content from top to bottom was "Yangfei Chuyu," "Dafugui," and "Hongyan Zhenghui" (Figure 2).

3.1.2. Organic Acid. Sugar, acid, and their interactions have an important effect on food flavor. The sugar acid ratio determines whether people love food, especially fresh food varieties. Acidity is determined by organic acid content, which is an important factor of flavor. During flower development, organic acid content in petals was firstly reduced and then increased. The lowest level appeared at the S2 period, with the amount of $11.70 \pm 0.45 \mathrm{mg} / \mathrm{g} \quad \mathrm{FW}, \quad 14.40 \pm 1.35 \mathrm{mg} / \mathrm{g} \quad \mathrm{FW}$, and $10.13 \pm 1.13 \mathrm{mg} / \mathrm{g}$ FW for "Dafugui," "Hongyan Zhenghui," and "Yangfei Chuyu," respectively (Figure 3). Organic acid content of flower petals at S1 and S2 periods varied significantly for all three cultivars. S2 and S3 periods, as well as S1 and S4 periods, had no significant difference in organic acid content for "Dafugui." Between S2, S3, and S4, some differences existed in "Hongyan Zhenghui" and "Yangfei Chuyu." "Yangfei Chuyu" contained the minimum level of organic acid for all four periods among three cultivars. The sugar acid ratio was calculated with soluble sugar and organic acid content from Figures 2 and 3, and the order of sugar acid ratio from top to bottom was S3, S2, S4, and S1. Sugar acid ratio of the S3 period reached the maximum level for all three cultivars, which is $14.09,5.88$, and 16.14 times of the S1 value for "Dafugui," "Hongyan Zhenghui," and "Yangfei Chuyu," respectively.

3.1.3. Protein. As an important nutrient needed by human body, protein content has become one of the important indexes to evaluate the quality of horticulture product. With flower development, protein content in petals of three cultivars was firstly increased and then reduced, with the minimum and maximum levels at S4 and S3, respectively. The highest amount at the S3 period for "Dafugui," "Hongyan Zhenghui," and "Yangfei Chuyu" is $39.17 \pm 0.39 \mathrm{mg} / \mathrm{g}$ FW, $44.94 \pm 0.37 \mathrm{mg} / \mathrm{g}$ FW, and $22.98 \pm 1.01 \mathrm{mg} / \mathrm{g} F W$, respectively. In addition, there was no significant difference in protein content of petals from "Dafugui" between the first 3 developmental stages, while the other 2 varieties showed significant difference of petal protein content in each period (Figure 4). 

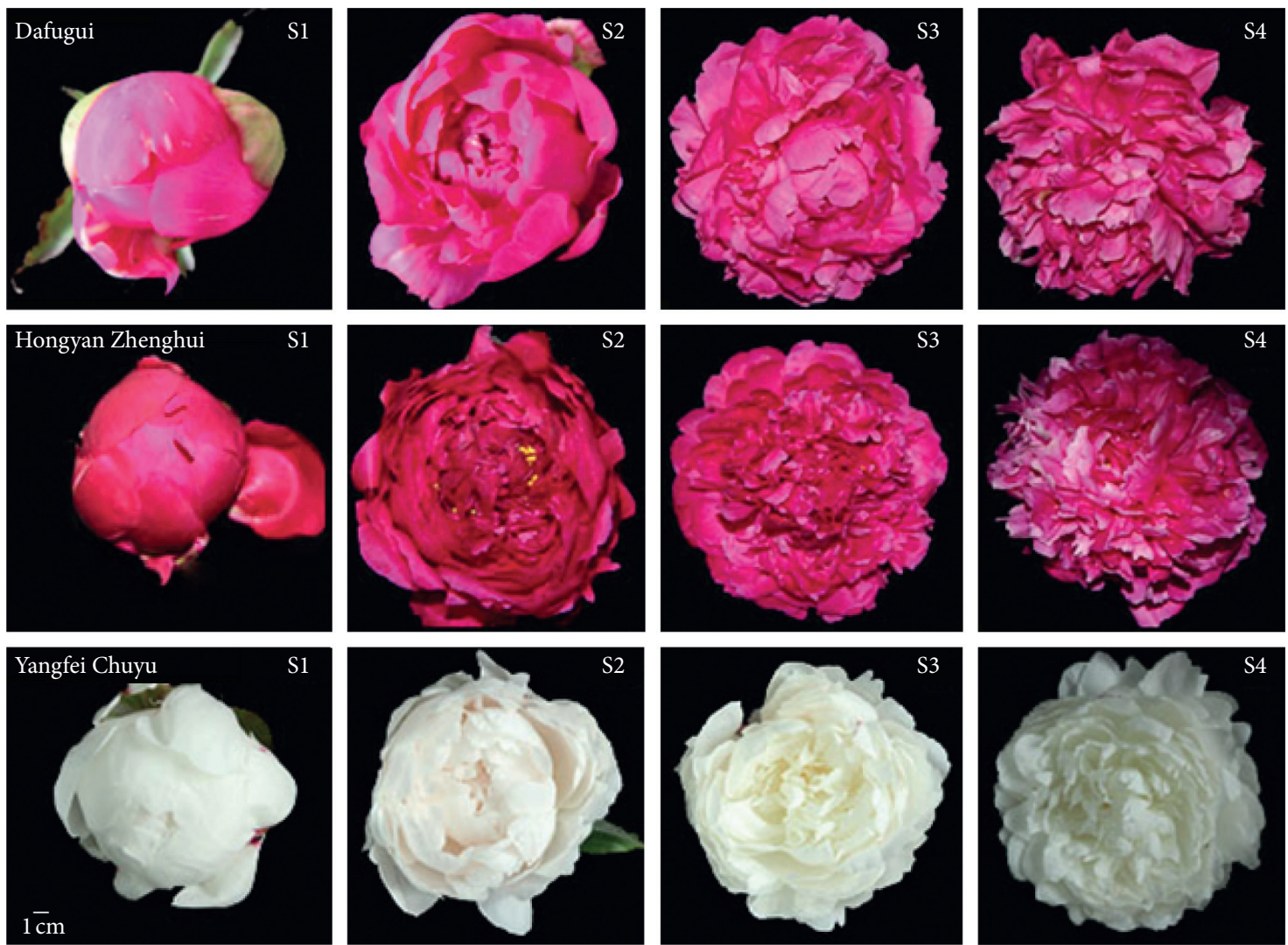

Figure 1: Petals of three P. lactiflora cultivars at different developmental stages.

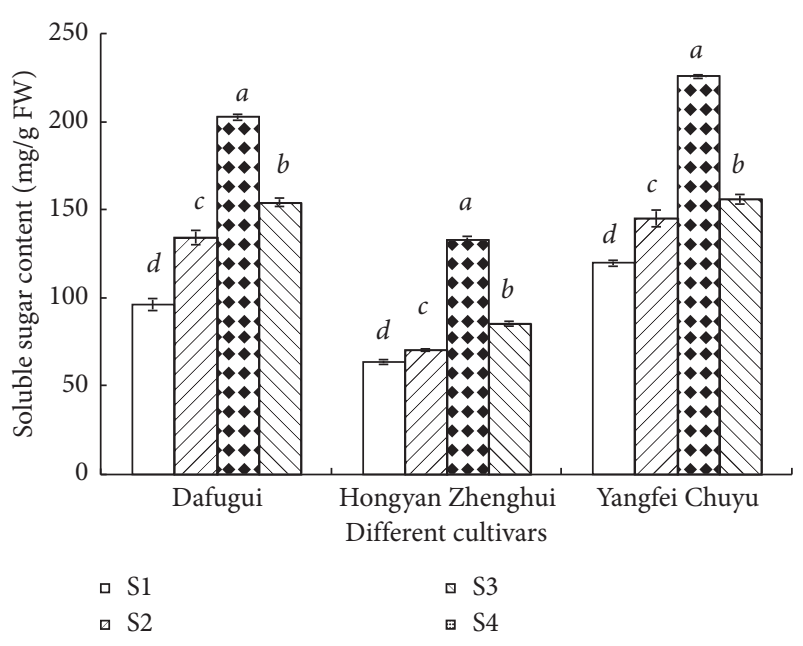

Figure 2: Soluble sugar content of developmental P. lactiflora petals $(\mathrm{mg} / \mathrm{g} \mathrm{FW}) .{ }^{*}$ Statistical analysis was carried out within each cultivar, respectively. Different letters within each cultivar indicated significant differences at $5 \%$ level.

3.1.4. Vitamin $C$. Vitamin $\mathrm{C}\left(\mathrm{V}_{\mathrm{C}}\right)$ is an essential nutrient for human body, which has antioxidant activity, and can reduce the threat of free radicals to human health (Pharmacopoeia of the People's Republic of China, 2005). The data in Figure 5 showed that $\mathrm{V}_{\mathrm{C}}$ content of petals increased initially and then reduced during flower development. The order of $\mathrm{V}_{\mathrm{C}}$ content from maximum to minimum was S2, S1, S3, and S4 for all three

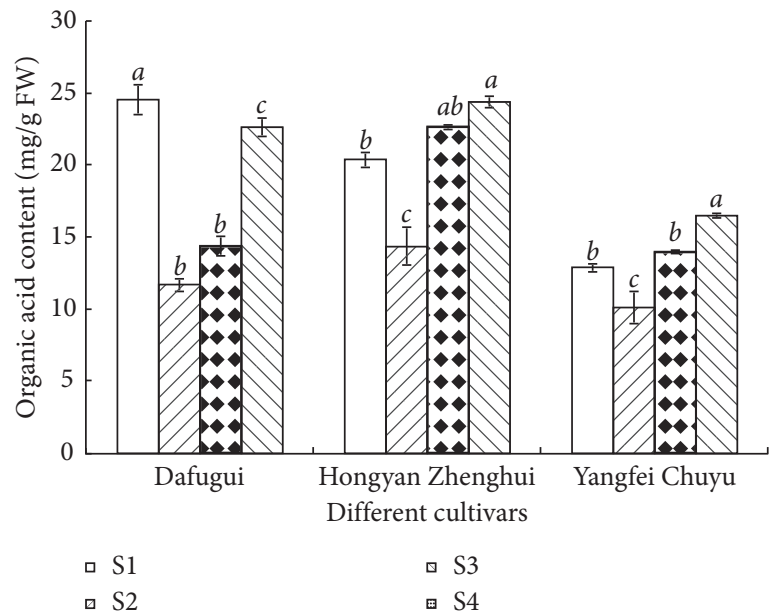

FIgURE 3: Organic acid content of developmental $P$. lactiflora petals (mg/g FW). Different letters within each cultivar indicated significant differences at $5 \%$ level.

cultivars. The highest $\mathrm{V}_{\mathrm{C}}$ amount for "Dafugui," "Yangfei Chuyu," and "Hongyan Zhenghui" was $19.81 \pm 1.22 \mathrm{mg} / 100 \mathrm{~g}$ FW, $13.04 \mathrm{mg} / 100 \mathrm{~g} \mathrm{FW}$, and $33.52 \pm 0.47 \mathrm{mg} / 100 \mathrm{~g} \mathrm{FW}$, respectively.

3.1.5. Mineral Element. The contents of ten mineral elements, including four macroelements potassium $(\mathrm{K})$, calcium $(\mathrm{Ca})$, sodium $(\mathrm{Na})$, and magnesium $(\mathrm{Mg})$ and six trace 


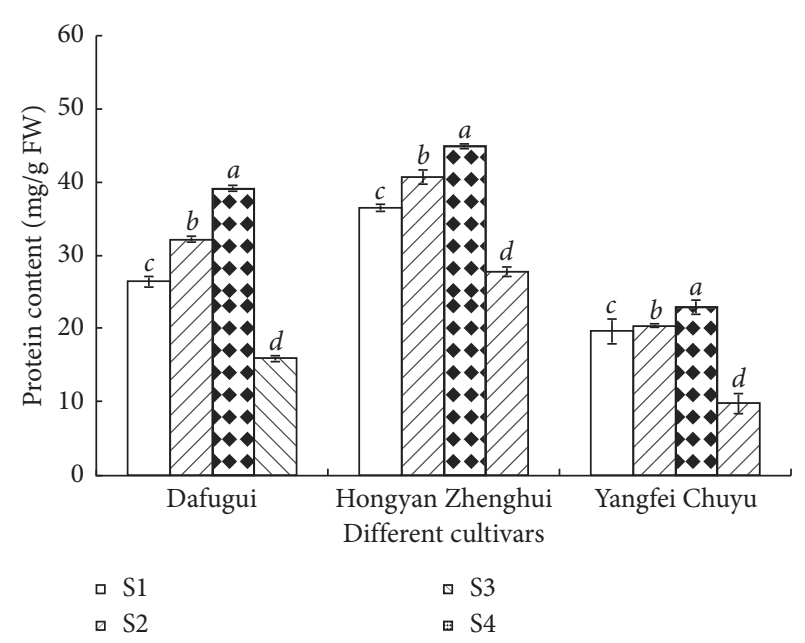

FIgURE 4: Protein content of developmental P. lactiflora petals $(\mathrm{mg} / \mathrm{g} \mathrm{FW})$. Different letters within each cultivar indicated significant differences at $5 \%$ level.

elements iron $(\mathrm{Fe})$, manganese $(\mathrm{Mn})$, zinc $(\mathrm{Zn})$, molybdenum $(\mathrm{Mo})$, nickel $(\mathrm{Ni})$, and chromium $(\mathrm{Cr})$, were analyzed with petals of "Dafugui," "Hongyan Zhenghui," and "Yangfei Chuyu" at four different developmental stages. The results showed that there was no $\mathrm{Cr}$ existing in herbaceous peony flower petals. Mo was only found in flower petals of "Dafugui" at the S1 period with the amount of $1.92 \pm 0.01 \mu \mathrm{g} /$ $\mathrm{g}$ DW. Petals of three cultivars at the S1 period contained the highest $\mathrm{Zn}$ content and the lowest $\mathrm{Na}, \mathrm{Mg}$, and $\mathrm{Fe}$ content. Petals of three cultivars at the S3 period contained the lowest $\mathrm{Mg}$ content and the highest $\mathrm{Mn}$ content. The contents of $\mathrm{Ca}$, $\mathrm{Fe}$, and $\mathrm{Ni}$ in flower petals reached their highest level at the S4 period. K content had no obvious tendency. The contents of other mineral elements also varied with cultivar (Table 1).

\subsection{Bioactive Component}

3.2.1. Total Phenolics. Total phenolic content of petals was between $83.23 \pm 0.25 \mathrm{mg} / \mathrm{g}$ DW and $136.19 \pm 8.22 \mathrm{mg} / \mathrm{g} \mathrm{DW}$ and showed slow reduction tendency with flower development (Figure 6). For the same cultivar, the total phenolic content at different stages demonstrated a certain degree of difference and that of S3 and S4 periods was significantly lower than that of S1 and S2 periods. Total phenolic content of S3 and S4 had no obvious difference for "Dafugui" and "Hongyan Zhenghui." Among three cultivars, "Hongyan Zhenghui" contained the highest amount of total phenolics, "Dafugui" had the lowest level of total phenolics, while "Yangfei Chuyu" was in between.

3.2.2. Total Flavonoids. Flavonoids have important health care function and can inhibit the free radical activity, thus delaying aging. Total flavonoid content of flower petals was between $10.20 \pm 0.07 \mathrm{mg} / \mathrm{g}$ DW and $10.20 \pm 0.07 \mathrm{mg} / \mathrm{g} \mathrm{DW}$ for three varieties (Figure 7). Total flavonoid content of different harvest seasons existed obvious difference for each cultivar. S1 period had the lowest amount of total flavonoids

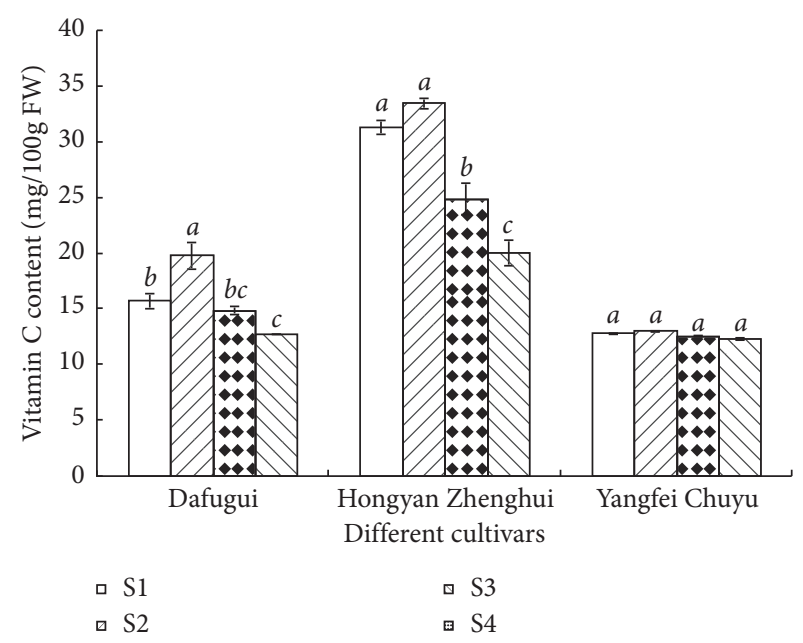

Figure 5: Vitamin C content of developmental P. lactiflora petals (mg/100 g FW). Different letters within each cultivar indicated significant differences at $5 \%$ level.

for three cultivars. The highest level appeared at the S3 period for "Dafugui" and "Yangfei Chuyu" and at the S4 period for "Hongyan Zhenghui." In addition, for different harvest times, the total flavonoid content of "Dafugui" and "Yangfei Chuyu" was higher than that of "Hongyan Zhenghui."

3.2.3. SOD Activity. As shown in Figure 8, the SOD activity of petals was increased initially and then reduced during flower development for all three cultivars, with the minimum amount at the S1 stage and the maximum amount at the S3 stage. The SOD activity in S3 was $233.35 \pm 5.61 \mathrm{U} / \mathrm{g} \mathrm{FW}, 284.09 \pm 15.00 \mathrm{U} / \mathrm{g}$ FW, and $157.95 \pm 7.93 \mathrm{U} / \mathrm{g}$ FW for "Dafugui," "Hongyan Zhenghui," and "Yangfei Chuyu," respectively, which has obvious difference with those of other stages. In addition, for different harvest times, the SOD activity of "Dafugui" and "Hongyan Zhenghui" was higher than that of "Yangfei Chuyu."

\section{Discussion}

The nutrient composition of herbaceous peony petals at different developmental stages was analyzed, and the results showed that the content of soluble sugar and protein displayed similar trend, with initial increase and then decrease with the highest amount appearing at the full bloom stage (S3). The result was similar to the conclusion of Yu [40]. Organic acid contents were firstly reduced and then increased, with higher amount at S1 and S4 and lower amount at S2 and S3. The contents of soluble sugar and organic acid can affect the eating quality of peony flowers. Petal and its processed products taste better with a higher sugar acid ratio [41]. The sugar acid ratio in flower petals reached the highest amount at S3 with the value of 14.09, 5.88, and 16.14 for "Dafugui," "Hongyan Zhenghui," and "Yangfei Chuyu," respectively. The Vc content of herbaceous peony petals was $12.31-33.52 \mathrm{mg} / 100 \mathrm{~g} \mathrm{FW}$, which was much higher than that of some Lamiaceae edible flowers $(1.14-2.57 \mathrm{mg} / 100 \mathrm{~g} \mathrm{FW})$ [42] but lower than that of apricot flowers $(24.97-43.75 \mathrm{mg} /$ 
TABLe 1: The mineral elements content of developmental P. lactiflora petals ( $\mu \mathrm{g} / \mathrm{g} \mathrm{DW})$.

\begin{tabular}{|c|c|c|c|c|c|}
\hline Element & Cultivar & S1 & S2 & S3 & S4 \\
\hline $\mathrm{Na}$ & $\begin{array}{c}\text { Dafugui } \\
\text { Hongyan Zhenghui } \\
\text { Yangfei Chuyu }\end{array}$ & $\begin{array}{l}30.34 \pm 0.03^{\mathrm{c}} \\
42.70 \pm 0.18^{\mathrm{b}} \\
20.96 \pm 0.10^{\mathrm{d}}\end{array}$ & $\begin{array}{l}44.72 \pm 0.02^{\mathrm{c}} \\
65.51 \pm 0.12^{\mathrm{a}} \\
41.06 \pm 0.11^{\mathrm{c}}\end{array}$ & $\begin{array}{l}54.62 \pm 0.09^{\mathrm{b}} \\
48.61 \pm 0.08^{\mathrm{b}} \\
64.05 \pm 0.24^{\mathrm{a}}\end{array}$ & $\begin{array}{l}82.82 \pm 0.18^{\mathrm{a}} \\
62.36 \pm 0.16^{\mathrm{a}} \\
49.17 \pm 0.09^{\mathrm{b}}\end{array}$ \\
\hline $\mathrm{Mg}$ & $\begin{array}{c}\text { Dafugui } \\
\text { Hongyan Zhenghui } \\
\text { Yangfei Chuyu }\end{array}$ & $\begin{array}{l}1342.36 \pm 37.04^{\mathrm{a}} \\
1091.03 \pm 20.34^{\mathrm{b}} \\
1264.32 \pm 50.31^{\mathrm{a}}\end{array}$ & $\begin{array}{l}959.55 \pm 47.38^{\mathrm{bc}} \\
1127.32 \pm 30.42^{\mathrm{b}} \\
1171.43 \pm 20.54^{\mathrm{b}}\end{array}$ & $\begin{array}{c}810.85 \pm 24.55^{\mathrm{c}} \\
1063.27 \pm 40.31^{\mathrm{b}} \\
1134.75 \pm 20.12^{\mathrm{b}}\end{array}$ & $\begin{array}{c}1178.99 \pm 38.93^{\mathrm{ab}} \\
1273.48 \pm 20.46^{\mathrm{a}} \\
1262.63 \pm 10.44^{\mathrm{a}}\end{array}$ \\
\hline $\mathrm{K}$ & $\begin{array}{c}\text { Dafugui } \\
\text { Hongyan Zhenghui } \\
\text { Yangfei Chuyu }\end{array}$ & $\begin{array}{c}10514.52 \pm 20.32^{\mathrm{a}} \\
9633.46 \pm 20.35^{\mathrm{c}} \\
11643.75 \pm 30.63^{\mathrm{a}}\end{array}$ & $\begin{array}{c}8194.57 \pm 40.15^{\mathrm{b}} \\
10859.27 \pm 10.66^{\mathrm{b}} \\
10432.46 \pm 40.54^{\mathrm{b}}\end{array}$ & $\begin{array}{c}6723.68 \pm 40.23^{\mathrm{b}} \\
10167.22 \pm 10.54^{\mathrm{bc}} \\
10583.33 \pm 20.36^{\mathrm{ab}}\end{array}$ & $\begin{array}{c}7871.38 \pm 36.56^{\mathrm{b}} \\
12253.63 \pm 20.01^{\mathrm{a}} \\
11392.76 \pm 10.59^{\mathrm{ab}}\end{array}$ \\
\hline $\mathrm{Ca}$ & $\begin{array}{c}\text { Dafugui } \\
\text { Hongyan Zhenghui } \\
\text { Yangfei Chuyu }\end{array}$ & $\begin{array}{c}1342.37 \pm 10.44^{\mathrm{b}} \\
848.67 \pm 10.66^{\mathrm{d}} \\
1634.11 \pm 20.66^{\mathrm{d}} \\
\end{array}$ & $\begin{array}{l}1193.35 \pm 7.33^{\mathrm{cd}} \\
1012.54 \pm 10.41^{\mathrm{c}} \\
1882.43 \pm 13.05^{\mathrm{c}} \\
\end{array}$ & $\begin{array}{c}993.87 \pm 30.01^{\mathrm{d}} \\
1476.46 \pm 20.22^{\mathrm{b}} \\
2319.76 \pm 31.03^{\mathrm{b}}\end{array}$ & $\begin{array}{c}2304.77 \pm 11.20^{\mathrm{a}} \\
2493.13 \pm 13.03^{\mathrm{a}} \\
3038.46 \pm 8.79^{\mathrm{a}} \\
\end{array}$ \\
\hline $\mathrm{Mn}$ & $\begin{array}{c}\text { Dafugui } \\
\text { Hongyan Zhenghui } \\
\text { Yangfei Chuyu }\end{array}$ & $\begin{array}{l}1.71 \pm 0.01^{\mathrm{d}} \\
1.14 \pm 0.00^{\mathrm{c}} \\
1.84 \pm 0.02^{\mathrm{c}}\end{array}$ & $\begin{array}{l}2.92 \pm 0.01^{\mathrm{c}} \\
5.16 \pm 0.02^{\mathrm{b}} \\
4.64 \pm 0.01^{\mathrm{b}}\end{array}$ & $\begin{array}{l}7.78 \pm 0.02^{\mathrm{a}} \\
8.44 \pm 0.02^{\mathrm{a}} \\
6.67 \pm 0.01^{\mathrm{a}}\end{array}$ & $\begin{array}{l}3.73 \pm 0.00^{\mathrm{b}} \\
4.72 \pm 0.00^{\mathrm{b}} \\
4.61 \pm 0.01^{\mathrm{b}}\end{array}$ \\
\hline $\mathrm{Fe}$ & $\begin{array}{c}\text { Dafugui } \\
\text { Hongyan Zhenghui } \\
\text { Yangfei Chuyu }\end{array}$ & $\begin{array}{l}53.50 \pm 0.05^{c} \\
50.33 \pm 0.28^{c} \\
48.70 \pm 0.25^{c}\end{array}$ & $\begin{array}{l}72.72 \pm 0.62^{\mathrm{b}} \\
56.24 \pm 0.18^{\mathrm{c}} \\
64.91 \pm 0.08^{\mathrm{b}} \\
\end{array}$ & $\begin{array}{l}57.25 \pm 0.08^{\mathrm{c}} \\
77.42 \pm 0.11^{\mathrm{b}} \\
49.39 \pm 0.11^{\mathrm{c}}\end{array}$ & $\begin{array}{c}138.99 \pm 0.11^{\mathrm{a}} \\
149.72 \pm 0.10^{\mathrm{a}} \\
95.72 \pm 0.11^{\mathrm{a}}\end{array}$ \\
\hline $\mathrm{Ni}$ & $\begin{array}{c}\text { Dafugui } \\
\text { Hongyan Zhenghui } \\
\text { Yangfei Chuyu }\end{array}$ & $\begin{array}{l}1.44 \pm 0.03^{\mathrm{a}} \\
1.52 \pm 0.01^{\mathrm{b}} \\
1.71 \pm 0.01^{\mathrm{bc}}\end{array}$ & $\begin{array}{c}1.71 \pm 0.05^{\mathrm{a}} \\
1.93 \pm 0.01^{\mathrm{ab}} \\
1.54 \pm 0.01^{\mathrm{c}}\end{array}$ & $\begin{array}{c}1.20 \pm 0.01^{\mathrm{a}} \\
1.68 \pm 0.00^{\mathrm{ab}} \\
1.96 \pm 0.01^{\mathrm{ab}}\end{array}$ & $\begin{array}{l}2.17 \pm 0.03^{\mathrm{a}} \\
1.99 \pm 0.01^{\mathrm{a}} \\
2.33 \pm 0.00^{\mathrm{a}}\end{array}$ \\
\hline $\mathrm{Zn}$ & $\begin{array}{c}\text { Dafugui } \\
\text { Hongyan Zhenghui } \\
\text { Yangfei Chuyu }\end{array}$ & $\begin{array}{l}25.50 \pm 0.09^{\mathrm{a}} \\
22.44 \pm 0.10^{\mathrm{a}} \\
26.50 \pm 0.01^{\mathrm{a}}\end{array}$ & $\begin{array}{l}20.53 \pm 0.11^{\mathrm{bc}} \\
18.71 \pm 0.02^{\mathrm{bc}} \\
24.41 \pm 0.01^{\mathrm{b}}\end{array}$ & $\begin{array}{l}18.67 \pm 0.23^{c} \\
16.69 \pm 0.03^{c} \\
22.76 \pm 0.01^{c}\end{array}$ & $\begin{array}{l}23.19 \pm 0.06^{\mathrm{bc}} \\
20.76 \pm 0.01^{\mathrm{ab}} \\
24.54 \pm 0.07^{\mathrm{b}}\end{array}$ \\
\hline Mo & $\begin{array}{c}\text { Dafugui } \\
\text { Hongyan Zhenghui } \\
\text { Yangfei Chuyu }\end{array}$ & $\begin{array}{c}1.92 \pm 0.01 \\
- \\
-\end{array}$ & $\begin{array}{l}- \\
- \\
-\end{array}$ & $\begin{array}{l}- \\
- \\
-\end{array}$ & $\begin{array}{l}- \\
- \\
-\end{array}$ \\
\hline $\mathrm{Cr}$ & $\begin{array}{c}\text { Dafugui } \\
\text { Hongyan Zhenghui } \\
\text { Yangfei Chuyu }\end{array}$ & $\begin{array}{l}- \\
- \\
-\end{array}$ & $\begin{array}{l}- \\
- \\
-\end{array}$ & $\begin{array}{l}- \\
- \\
-\end{array}$ & $\begin{array}{l}- \\
- \\
-\end{array}$ \\
\hline
\end{tabular}

Note: - means not detected.

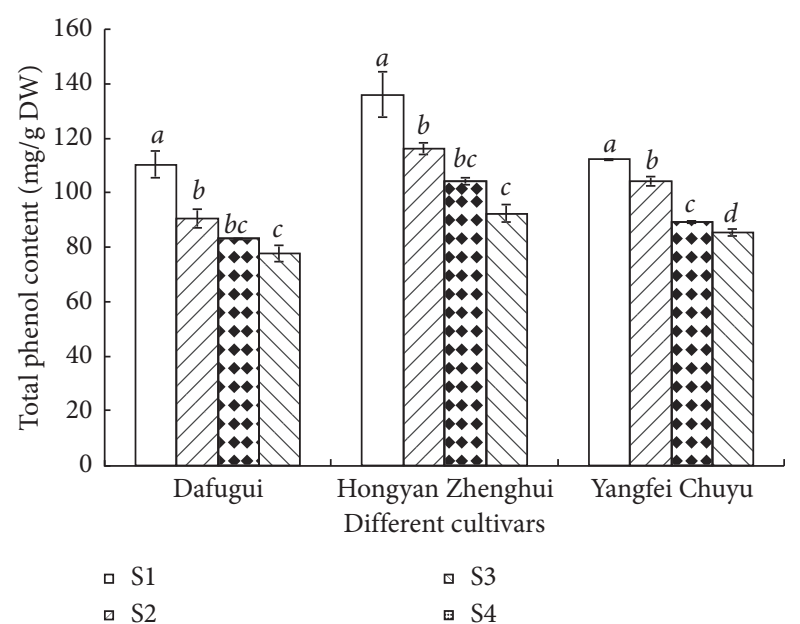

Figure 6: Total phenol content of developmental P. lactiflora petals (mg/g DW). Different letters within each cultivar indicated significant differences at $5 \%$ level.

$100 \mathrm{~g} \mathrm{FW)} \mathrm{[43].} \mathrm{We} \mathrm{also} \mathrm{investigated} \mathrm{the} \mathrm{content} \mathrm{of} \mathrm{bioactive}$ components in flower petals at different periods and found that total phenolic content was higher at S1 and S4 while lower at S2 and S3. This result was similar to that of Wang

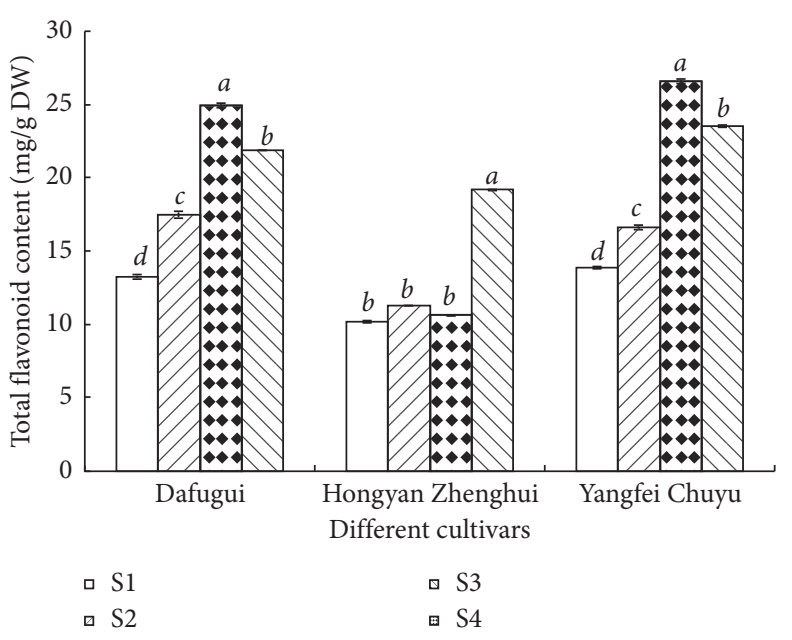

Figure 7: Total flavonoid content of developmental P. lactiflora petals $(\mathrm{mg} / \mathrm{g} \mathrm{DW})$. Different letters within each cultivar indicated significant differences at 5\% level.

and Liu [44]. According to the opinion of Zhang et al. [45], the taste and color are better with less phenolics; therefore, the petal picked at S2 and S3 was much better. The flavonoid content and SOD activity of flower petals were the highest at 


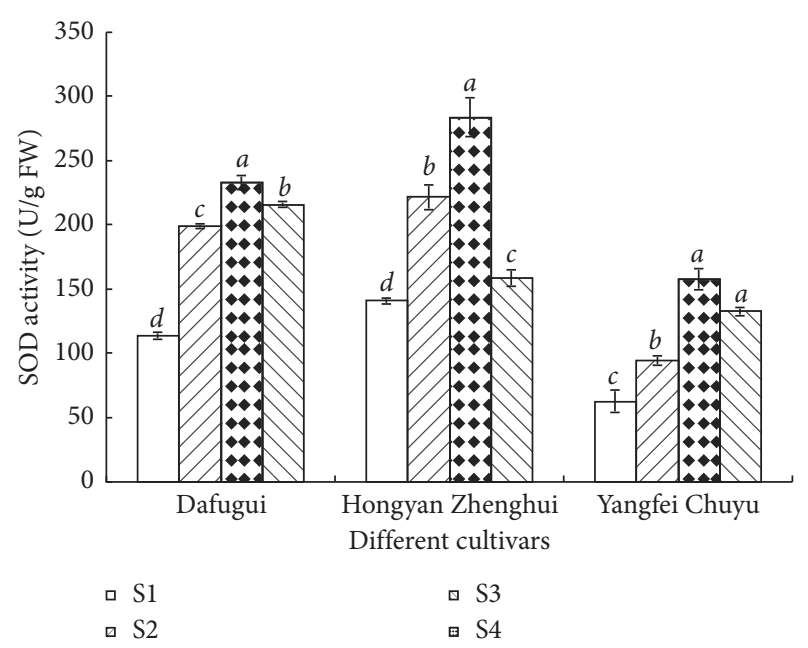

FIGURE 8: SOD activity of developmental P. lactiflora petals (U/g FW). Different letters within each cultivar indicated significant differences at $5 \%$ level.

S3 and had significant difference with those of other three developmental periods. The contents of individual mineral element varied with cultivar and developmental stage. At S1, the content of $\mathrm{Zn}$ was the highest, while the contents of $\mathrm{Na}$, $\mathrm{Mg}$, and Fe were the lowest. At S3, the content of Mg was the highest, while the content of Mn was the lowest. The content of $\mathrm{Ca}, \mathrm{Fe}$, and $\mathrm{Ni}$ was the highest at $\mathrm{S} 4$. The content of other elements in the three cultivars showed different trends with variety distinctness.

Besides above detected ingredients, the amino acid in protein and the individual components of phenolics and flavonoids should further be characterized and quantified. Furthermore, biological activity and toxicology also need to be investigated in the near future.

\section{Conclusions}

In summary, herbaceous peony petals at S3 had the best edible quality considering nutrients and bioactive components analyzed in this research. At this stage, herbaceous peony petals contained the highest soluble sugar, protein, total flavonoids, and SOD activity, which may contribute to their nutritional and biological values. Thus, S3 was recommended to be the optimal harvest time for edible herbaceous peony flowers.

\section{Data Availability}

All the data are included in the manuscript.

\section{Conflicts of Interest}

The authors declare that they have no conflicts of interest.

\section{Authors' Contributions}

All authors made considerable contributions to the manuscript. CZ, JT, and WL designed the study. WL, YH, and XS performed the experiments. WL, XS, and YH interpreted the results. WL, XS, JT, and CZ wrote the manuscript. All authors revised the manuscript and approved it for publication.

\section{Acknowledgments}

This work was financially sponsored by the Jiangsu Agricultural Science and Technology Innovation Fund (CX (18) 2021) and Excellent Youth Backbone Teachers of Yangzhou University (2014).

\section{References}

[1] E. Lara-Cortes, P. Osorio-Diaz, A. Jimenez-Aparicio, and S. Bautista-Banos, "Nutritional content, functional properties and conservation of edible flowers. review," Archivos Latinoamericanos de Nutrition, vol. 63, no. 3, pp. 197-208, 2013.

[2] M. Grzeszczuk, A. Stefaniak, and A. Pachlowska, "Biological value of various edible flower species," Acta Scientiarum Polonorum Hortorum Cultus, vol. 15, no. 2, pp. 109-119, 2016.

[3] N.-H. Chen and S. Wei, "Factors influencing consumers' attitudes towards the consumption of edible flowers," Food Quality and Preference, vol. 56, pp. 93-100, 2017.

[4] E. Matyjaszczyk and M. Śmiechowska, "Edible flowers. Benefits and risks pertaining to their consumption," Trends in Food Science \& Technology, vol. 91, pp. 670-674, 2019.

[5] M. Grzeszczuk, A. Wesolowska, D. Jadczak, and B. Jakubowska, "Nutritional value of chive edible flowers," Acta Scientiarum Polonorum Hortorum Cultus, vol. 10, no. 2, pp. 85-94, 2011.

[6] A. Sotelo, S. López-García, and F. Basurto-Peña, "Content of nutrient and antinutrient in edible flowers of wild plants in Mexico," Plant Foods for Human Nutrition, vol. 62, no. 3, pp. 133-138, 2007.

[7] B. Matthäus and M. M. Özcan, "Chemical evaluation of flower bud and oils of tumbleweed (Gundelia tourneforti L.) as a new potential nutrition sources," Journal of Food Biochemistry, vol. 35, no. 4, pp. 1257-1266, 2011

[8] O. Rop, J. Mlcek, T. Jurikova, J. Neugebauerova, and J. Vabkova, "Edible flowers-a new promising source of mineral elements in human nutrition," Molecules, vol. 17, no. 6, pp. 6672-6683, 2012.

[9] O. Bayram, O. Sagdic, and L. Ekici, "Natural food colorants and bioactive extracts from some edible flowers," Journal of Applied Botany and Food Quality, vol. 88, pp. 170-176, 2015.

[10] S. Benvenuti, E. Bortolotti, and R. Maggini, "Antioxidant power, anthocyanin content and organoleptic performance of edible flowers," Scientia Horticulturae, vol. 199, pp. 170-177, 2016.

[11] A. Rachkeeree, K. Kantadoung, R. Suksathan, R. Puangpradab, P. A. Page, and S. R. Sommano, "Nutritional compositions and phytochemical properties of the edible flowers from selected Zingiberaceae found in Thailand," Frontiers in Nutrition, vol. 5, no. 3, 2018.

[12] R. González-Barrio, M. J. Periago, C. Luna-Recio, F. J. GarciaAlonso, and I. Navarro-González, "Chemical composition of the edible flowers, pansy (Viola wittrockiana) and snapdragon (Antirrhinum majus) as new sources of bioactive compounds," Food Chemistry, vol. 252, pp. 373-380, 2018.

[13] E. A. R. Espejel, O. C. Alvarez, J. M. M. Muñoz, M. D. R. G. Mateos, M. T. B. C. León, and M. T. M. Damián, "Physicochemical quality, antioxidant capacity and 
nutritional value of edible flowers of some wild dahlia species," Folia Horticulturae, vol. 31, no. 2, pp. 331-342, 2019.

[14] J. M. Pinedo-Espinoza, J. Gutiérrez-Tlahque, Y. O. SantiagoSaenz, C. L. Aguirre-Mancilla, M. Reyes-Fuentes, and C. U. López-Palestina, "Nutritional composition, bioactive compounds and antioxidant activity of wild edible flowers consumed in semiarid regions of Mexico," Plant Foods For Human Nutrition, vol. 75, no. 3, pp. 413-419, 2020.

[15] J. Shi, J. Gong, J. E. Liu, X. Wu, and Y. Zhang, "Antioxidant capacity of extract from edible flowers of Prunus mume in China and its active components," LWT-Food Science and Technology, vol. 42, no. 2, pp. 477-482, 2009.

[16] J. He, T. Yin, Y. Chen et al., "Phenolic compounds and antioxidant activities of edible flowers of Pyrus pashia," Journal of Functional Foods, vol. 17, pp. 371-379, 2015.

[17] A. Koike, J. C. M. Barreira, L. Barros, C. Santos-Buelga, A. L. C. H. Villavicencio, and I. C. F. R. Ferreira, "Edible flowers of Viola tricolor L. as a new functional food: antioxidant activity, individual phenolics and effects of gamma and electron-beam irradiation," Food Chemistry, vol. 179, pp. 6-14, 2015.

[18] R. Tundis, M. Marrelli, F. Conforti, M. C. Tenuta, M. Bonesi, and F. Menichini, "Trifolium pratense and T. repens (Leguminosae): edible flower extracts as functional ingredients," Foods, vol. 4, no. 3, pp. 338-348, 2015.

[19] M. R. Loizzo, A. Pugliese, M. Bonesi et al., "Edible flowers: a rich source of phytochemicals with antioxidant and hypoglycemic properties," Journal of Agricultural and Food Chemistry, vol. 64, no. 12, pp. 2467-2474, 2015.

[20] B. Lu, M. Li, and R. Yin, "Phytochemical content, health benefits, and toxicology of common edible flowers: a review (2000-2015)," Critical Reviews in Food Science and Nutrition, vol. 56, no. sup1, pp. S130-S148, 2016.

[21] R. Omidbaigi, B. Dadman, and S. Yavari, "Various harvest times of Tanacetum parthenium cv. Zardband flowers affecting its oil content and compositions," Journal of Essential Oil Bearing Plants, vol. 10, no. 4, pp. 287-291, 2007.

[22] M. Rafieiolhossaini, A. Adams, N. De Kimpe, and P. Van Damme, "Determination of best harvest time of German chamomile (Matricaria chamomilla L.) flowers based on solid-phase microextraction-GC-MS analysis data," Planta Medica, vol. 75, no. 9, p. 1000, 2009.

[23] J. Zhang, J. Wang, X. Fang, S. Yang, P. Meng, and L. Dong, "Dynamic changes of four kinds of polyphenol contents from flowers and leaves of Lonicera japonica Thunb at different collecting periods," Lishizhen Medicine and Materia Medica Research, vol. 25, no. 8, pp. 1985-1987, 2014.

[24] N. Jia, Q.-Y. Shu, L.-S. Wang, H. Du, Y.-J. Xu, and Z.-A. Liu, "Analysis of petal anthocyanins to investigate coloration mechanism in herbaceous peony cultivars," Scientia Horticulturae, vol. 117, no. 2, pp. 167-173, 2008.

[25] C. Zhou, Y. Zhang, Y. Sheng et al., "Herbaceous peony (Paeonia lactiflora Pall.) as an alternative source of oleanolic and ursolic acids," International Journal of Molecular Sciences, vol. 12, no. 1, pp. 655-667, 2011.

[26] Y.-S. Jin, Y.-H. Xuan, Y.-Z. Jin, M.-L. Chen, and J. Tao, "Biological activities of herbaceous peony flower extracts," Asian Journal of Chemistry, vol. 25, no. 7, pp. 3835-3838, 2013.

[27] P. Liu, X. Q. Shao, Y. F. Ding, X. D. Liu, T. L. Wang, and X. R. Wang, "Comparison of nutrient contents in petals of different herbaceous peony cultivars," Northern Horticulture, vol. 1, pp. 151-153, 2014, in Chinese.
[28] C. Ning, Y. Jiang, J. Meng, C. Zhou, and J. Tao, "Herbaceous peony seed oil: a rich source of unsaturated fatty acids and $\gamma$-tocopherol," European Journal of Lipid Science and Technology, vol. 117, no. 4, pp. 532-542, 2015.

[29] L. Feng, Y. Li, L. Sheng, T. Li, D. Zhao, and J. Tao, "Comparative analysis of headspace volatiles of different herbaceous peony (Paeonia lactiflora Pall.) cultivars," Journal of Essential Oil Bearing Plants, vol. 19, no. 1, pp. 167-175, 2016.

[30] W. Li, S. Yang, H. Cui, Y. Hua, J. Tao, and C. Zhou, "Nutritional evaluation of herbaceous peony (Paeonia lactiflora Pall.) petals," Emirates Journal of Food and Agriculture, vol. 29, no. 7, pp. 518-531, 2017.

[31] X. J. Hou, Y. L. Zhu, and X. J. Hou, "Effects of root of herbaceous peony on lipid metabolism of rheumatoid arthritis patients," Heart, vol. 98, no. S2, p. E289, 2012.

[32] D. Zhao, Y. Jiang, C. Ning et al., "Transcriptome sequencing of a chimaera reveals coordinated expression of anthocyanin biosynthetic genes mediating yellow formation in herbaceous peony (Paeonia lactiflora Pall.)," BMC Genomics, vol. 15, no. 1, p. 689, 2014.

[33] Y.-Q. Wu, M.-R. Wei, D.-Q. Zhao, and J. Tao, "Flavonoid content and expression analysis of flavonoid biosynthetic genes in herbaceous peony (Paeonia lactiflora Pall.) with double colors," Journal of Integrative Agriculture, vol. 15, no. 9, pp. 2023-2031, 2016.

[34] D.-Q. Zhao, M.-R. Wei, D. Liu, and J. Tao, "Anatomical and biochemical analysis reveal the role of anthocyanins in flower coloration of herbaceous peony," Plant Physiology and Biochemistry, vol. 102, pp. 97-106, 2016.

[35] S. Gao, C. Wei, Y. Wang, M. Lv, and B. Fan, "Effects of harvest Sstage on ornamental quality of cut flowers of herbaceous peony (Paeonia lactiflora Pall.)," Journal of Henan Agricultural Sciences, vol. 42, no. 10, pp. 115-117, 121, in Chinese.

[36] P. Liu and M. J. Li, Experimental Techniques of Plant Physiology, Science Publishing Company, Beijing, China, 2007.

[37] A. F. Ahmed, H. Yu, X. Yang, and W. Jiang, "Deficit irrigation affects growth, yield, vitamin $\mathrm{C}$ content, and irrigation water use efficiency of hot pepper grown in soilless culture," HortScience, vol. 49, no. 6, pp. 722-728, 2014.

[38] Y. Du, J. H. Sheng, X. S. Cui, Z. X. Zhai, X. H. Dong, and Y. H. Guo, "Determination of the content of mineral elements in Cistanche tubulosa from different areas," Spectroscopy and Spectral Analysis, vol. 32, no. 10, pp. 2824-2827, 2012.

[39] D. Huang, B. Ou, and R. L. Prior, "The chemistry behind antioxidant capacity assays," Journal of Agricultural and Food Chemistry, vol. 53, no. 6, pp. 1841-1856, 2005.

[40] N. Yu, "The senescence physiology and regulation of herbaceous peony and analysis of nutrition and health components in petals of main varities of poeny," Master thesis, Henan Normal University, Xinxiang, China, 2011, in Chinese.

[41] H. D. Xu, Flower Food, The China Light Industry Press, Beijing, China, 1st edition, 2000.

[42] I. Marchioni, B. Najar, B. Ruffoni, A. Copetta, L. Pistelli, and L. Pistelli, "Bioactive compounds and aroma profile of some Lamiaceae edible flowers," Plants, vol. 9, no. 6, p. 691, 2020.

[43] M. Göttingerová, M. Kumšta, and T. Nečas, "Healthbenefitting biologically active substances in edible apricot flowers," Hort Science, vol. 55, no. 8, pp. 1372-1377, 2020.

[44] R. H. Wang and Y. L. Liu, "Changes and determination of the fatty acid composition of Peony and Chinese Peony flower," Chinese Agricultural Science Bulletin, vol. 20, no. 6, pp. 212-214, 2004.

[45] Y. Zhang, J. Liang, and B. D. Zheng, "Processing quality and health-caring quality of thirteen edible flowers in China," Fujian Journal of Agricultural Sciences, vol. 20, no. S1, pp. 113-116, 2005, in Chinese. 